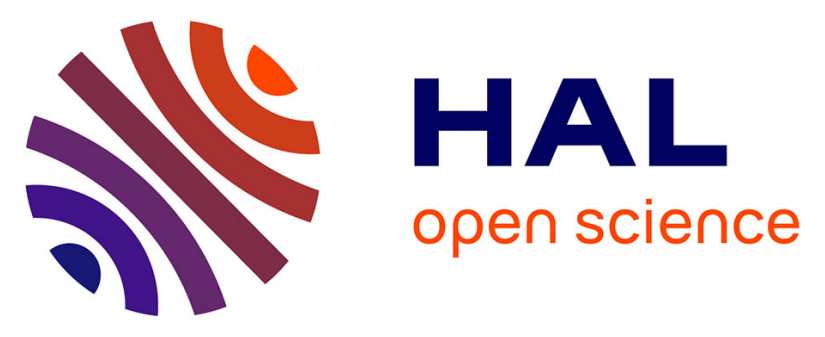

\title{
Porous Silicon Preparation by Electrochemical Etching in Ionic Liquids
}

\author{
Evgeniya A. Saverina, Daria Y. Zinchenko, Sofia D. Farafonova, Alexey S. \\ Galushko, Andrei Novikov, Maxim Gorbachevskii, Valentine P. Ananikov, \\ Mikhail P. Egorov, Viatcheslav Jouikov, Mikhail A. Syroeshkin
}

\section{To cite this version:}

Evgeniya A. Saverina, Daria Y. Zinchenko, Sofia D. Farafonova, Alexey S. Galushko, Andrei Novikov, et al.. Porous Silicon Preparation by Electrochemical Etching in Ionic Liquids. ACS Sustainable Chemistry \& Engineering, 2020, 8 (27), pp.10259-10264. 10.1021/acssuschemeng.0c03133 . hal02928603

\section{HAL Id: hal-02928603 https://hal.science/hal-02928603}

Submitted on 10 Sep 2020

HAL is a multi-disciplinary open access archive for the deposit and dissemination of scientific research documents, whether they are published or not. The documents may come from teaching and research institutions in France or abroad, or from public or private research centers.
L'archive ouverte pluridisciplinaire HAL, est destinée au dépôt et à la diffusion de documents scientifiques de niveau recherche, publiés ou non, émanant des établissements d'enseignement et de recherche français ou étrangers, des laboratoires publics ou privés. 


\section{Porous silicon preparation by electrochemical etching in ionic liquids}

Evgeniya A. Saverina, ${ }^{1,2}$ Daria Yu. Zinchenko, ${ }^{1}$ Sofia D. Farafonova, ${ }^{1,3}$ Alexey S.

Galushko, $^{1}$

Andrei A. Novikov, ${ }^{4}$ Maxim V. Gorbachevskii, ${ }^{4}$ Valentine P. Ananikov, ${ }^{1}$ Mikhail P.

Egorov, $^{1}$

Viatcheslav V. Jouikov, ${ }^{\star 2}$ Mikhail A. Syroeshkin*1

${ }^{1}$ N. D. Zelinsky Institute of Organic Chemistry, Moscow, Russia

2University of Rennes, UMR CNRS 6226, ISCR (Institut des Sciences Chimiques de

Rennes), Rennes, France

${ }^{3}$ Dmitry Mendeleev University of Chemical Technology of Russia, Moscow, Russia

${ }^{4}$ Gubkin University, Moscow, 119991, Russia 


\begin{abstract}
Keywords: porous silicon, electrochemical etching, HF-free, fluorescence, confocal
microscopy, green chemistry.
\end{abstract}

\begin{abstract}
Anodic etching of $n$-type $\{111\}$ silicon in ionic liquid (IL) systems ([RMIM][X], $R$ $\left.=\mathrm{H}, \mathrm{Bu} ; \mathrm{X}=\mathrm{BF}_{4}^{-}, \mathrm{PF}_{6}^{-}\right)$, realized under galvanostatic conditions and room temperature, allowed the formation of porous silicon surfaces with different pore morphology depending on the etching time, current density and the IL used. The study of the effect of water content in IL on the etching process has shown water content of $1 \%$ to be optimal. The role of the anion on the etching process was elucidated using 1methylimidazolium tetrafluoroborate $\left.\left([\mathrm{HMIM}] \mathrm{BF}_{4}\right]\right)$ and 1-methylimidazolium hexafluorophosphate $\left([\mathrm{HMIM}]\left[\mathrm{PF}_{6}\right]\right)$ IL systems. $[\mathrm{HMIM}]\left[\mathrm{BF}_{4}\right]$ was found to be most efficient for the formation of silicon nanostructured array with a pore size of $30-80 \mathrm{~nm}$.
\end{abstract} The thus prepared porous silicon samples show fluorescence in blue light $(475 \mathrm{~nm})$.

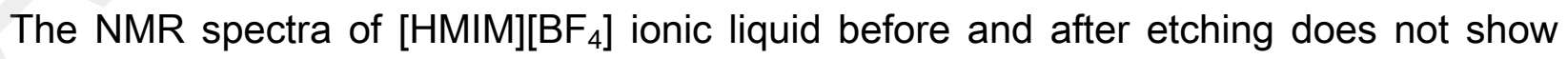


noticeable changes, which makes possible to consider this $\mathrm{IL}$ as a potentially recyclable etching agent.

\section{Introduction}

Silicon-based materials, in particular porous silicon (PSi), are of high demand in the materials science. Besides dominating solar cells market ${ }^{[1-4]}$ silicon and its porous form are widely used in various research fields such as optoelectronics, ${ }^{[5-6]}$ biosensing ${ }^{[7-9]}$ and biomedical applications. ${ }^{[10-16]}$

The primary method of obtaining PSi is oxidative etching of a non-porous silicon precursor in hydrofluoric acid solutions. ${ }^{[17]}$ In electrochemical version of silicon etching in fluoride solutions the process can be carried out both in potentiostatic and in galvanostatic mode; the latter option is often preferable because of easier control of the process. ${ }^{[9]}$ 


\begin{abstract}
Although the extreme safety hazards of hydrofluoric acid for nature and humans are well known, ${ }^{[18]}$ using HF in PSi production seems unavoidable since it is needed for removal of native oxides on silicon surface and for binding silicon in etching products.
\end{abstract}

The search for different approaches for replacing HF acid by more environmentalfriendly agents is of great interest in the field of silicon etching ${ }^{[19,20]}$ and in other areas of materials science. ${ }^{[21-23]}$

A method of silicon etching replacing HF with silicophilic reagents, in particular, salts of pyridine or $\mathrm{N}$-aromatic bases with tetrafluoroboric acid in an organic solvent was previously proposed. ${ }^{[19]}$ It should be noted that for etching silicon in such systems, it is necessary to use the salts solutions of high concentration. In this regard, etching systems based on protic ionic liquids, ${ }^{[24]}$ combining solvent and supporting salt in one compound ${ }^{[25-26]}$ that were successfully used in surface electro-chemistry ${ }^{[27]}$ might be more promising. 
Besides entirely merited attention and wide use in almost all chemistry-related areas, ${ }^{[28-}$

${ }^{31]}$ ionic liquids permit to address and in many cases to improve very important

ecological issues.

In this work, we propose a simple, environment-friendly, and efficient technique for

preparing porous silicon by means of an HF-free electrochemical etching in the ionic liquid medium (primarily derivatives of 1-methylimidazolium, [HMIM][BF 4$]$ ). This method allows one to prepare a uniformly porous silicon surface with the possibility of controlling the pore size.

\section{Results and discussion}

The $[\mathrm{HMIM}]\left[\mathrm{BF}_{4}\right]$ ionic liquid was synthesized by stirring 1-methylimidazole with tetrafluoroboric acid in appr. 1:1 molar ratio with minimal excess of 1-methylimidazole to prevent the presence of $\mathrm{HBF}_{4}$ in product. After that, the resulting solution was evaporated, washed with ethyl acetate and dried under vacuum according to [32].

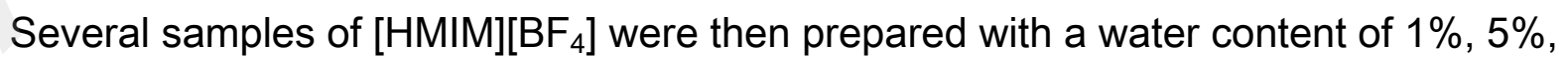
and $10 \%$, controlled by Fischer titration. ${ }^{[33]}$ Synthesized in the similar way $\left[{\mathrm{HMIM}]\left[\mathrm{PF}_{6}\right]}\right]$ 
was conditioned to water content of $2 \%$. In contrast to dry ILs, such wet ionic liquids (wIL) remain liquid at room temperature; this enables using them for silicon etching under the ambient conditions without heating which is otherwise needed to liquefy these ILs.

These w-IL were then tested for etching silicon and revealing the influence of current density and etching time on the morphology of the obtained samples.

A polished n-type (111) oriented single-crystal silicon wafer was used (Fig. S1) for this purpose. The etching was carried out at room temperature in a galvanostatic mode, using a specially designed polytetrafluorethylene (PTFE) cell (Fig. 1). The cell was fitted with a PTFE nut with a $4 \mathrm{~mm}$ hole protecting the Si sample so that the etching area, limited by the hole, remains constant throughout all experiments. A platinum grid was used as a cathode. 

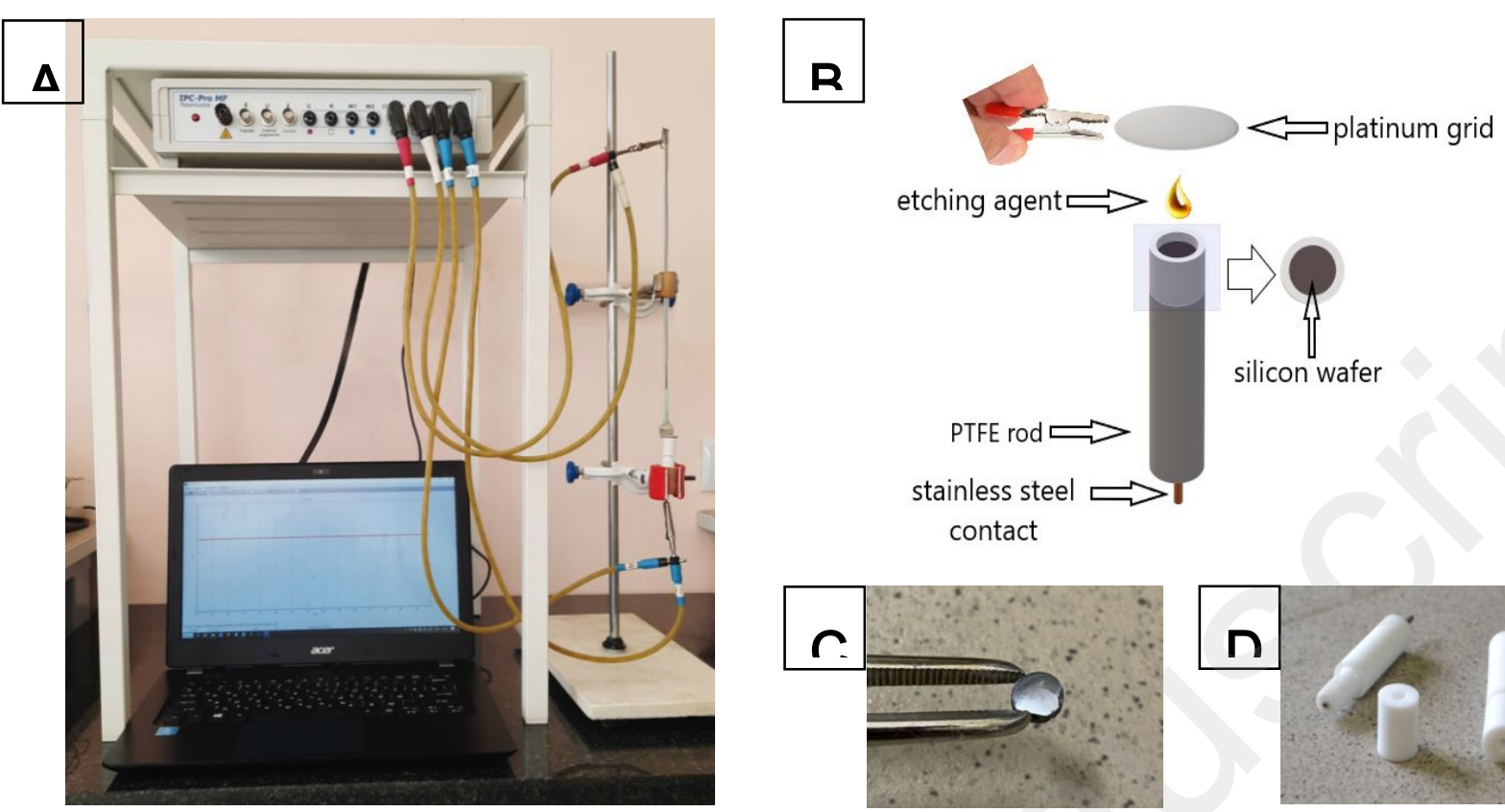

Figure 1. Photograph of a silicon etching setup (A), the scheme of assembling the

etching PTFE cell (B), a polished silicon wafer used in the experiments (C), and a PTFE cell (D) for mounting the sample for etching.

We found that etching in $1 \%\left[\mathrm{HMIM}_{[}\left[\mathrm{BF}_{4}\right] \mathrm{w}-\mathrm{IL}\right.$ system at a current density $\mathrm{j}=8 \mathrm{~mA} / \mathrm{cm}^{2}$ during 30 min results in the development of significant roughness of the surface of silicon wafer (Fig. 2 left). Further increase in etching time leads to the formation of a porous surface.

In particular, a uniform mesoporous surface with the irregularly shaped pores sized of $31 \pm 2 \mathrm{~nm}$ separated by $8 \pm 1 \mathrm{~nm}$ walls was obtained after a 5 hours etching (Fig. 2 right). 

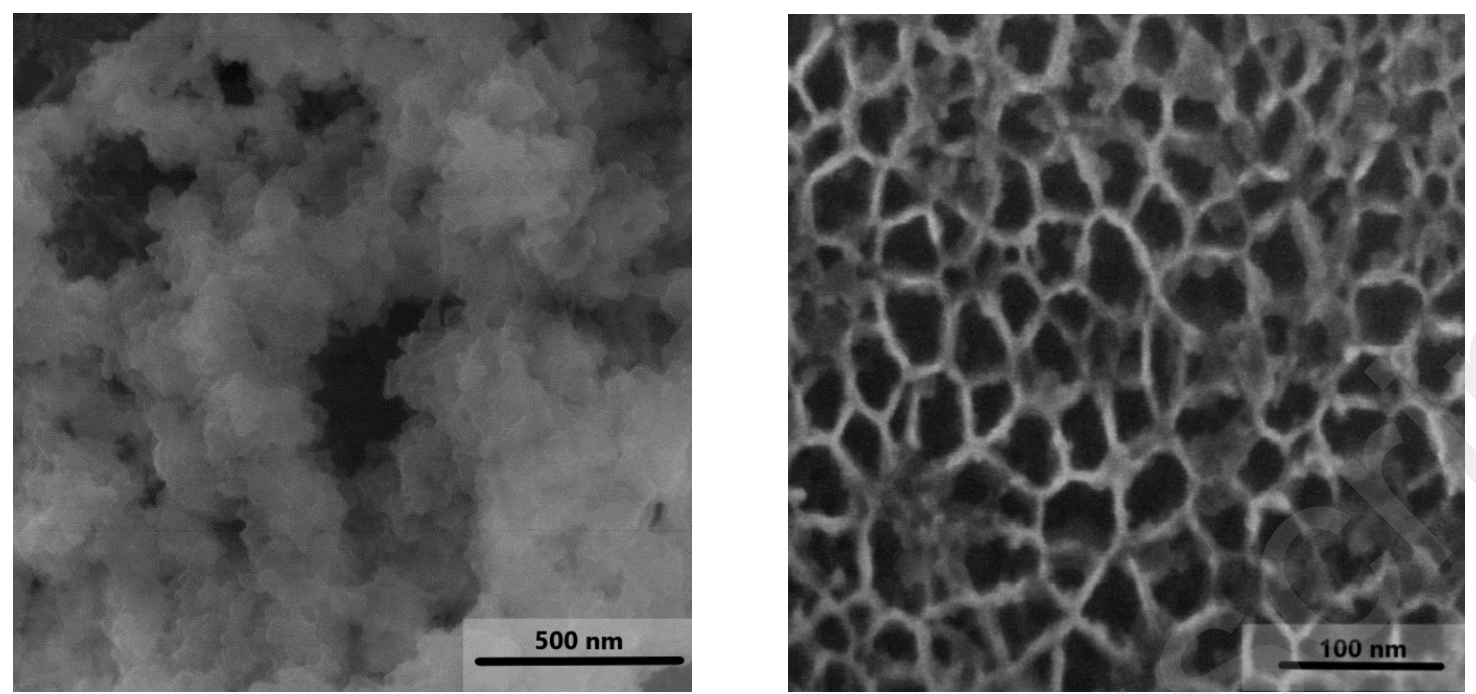

Figure 2. Scanning electron microscope (SEM) images of porous silicon obtained by

etching in $1 \%[\mathrm{HMIM}]\left[\mathrm{BF}_{4}\right] \mathrm{w}$-IL system at a current density $8 \mathrm{~mA} / \mathrm{cm}^{2}$ during 30 minutes

(left) and 5 hours (right).

When etching in HF-based systems, higher current densities are known to increase the pore size and depth. ${ }^{34-35]}$ This trend was also observed during the etching of silicon in [HMIM] $\left[\mathrm{BF}_{4}\right]$-based w-IL system. Fig. 3 shows an scanning electron microscope (SEM) picture of the sample obtained by etching a silicon wafer at $\mathrm{j}=24 \mathrm{~mA} / \mathrm{cm}^{2}$ for 1 hour.

It can be seen that the pores at thus prepared homogeneous porous surface are larger than those observed after etching for 5 hours at $\mathrm{j}=8 \mathrm{~mA} / \mathrm{cm}^{2}$. Now, the pore size and 
the thickness of the separating walls are increased up to $79 \pm 6 \mathrm{~nm}$ and $21 \pm 1 \mathrm{~nm}$, respectively. It is noteworthy that the majority of the cells formed are 4 or 5 -faceted.

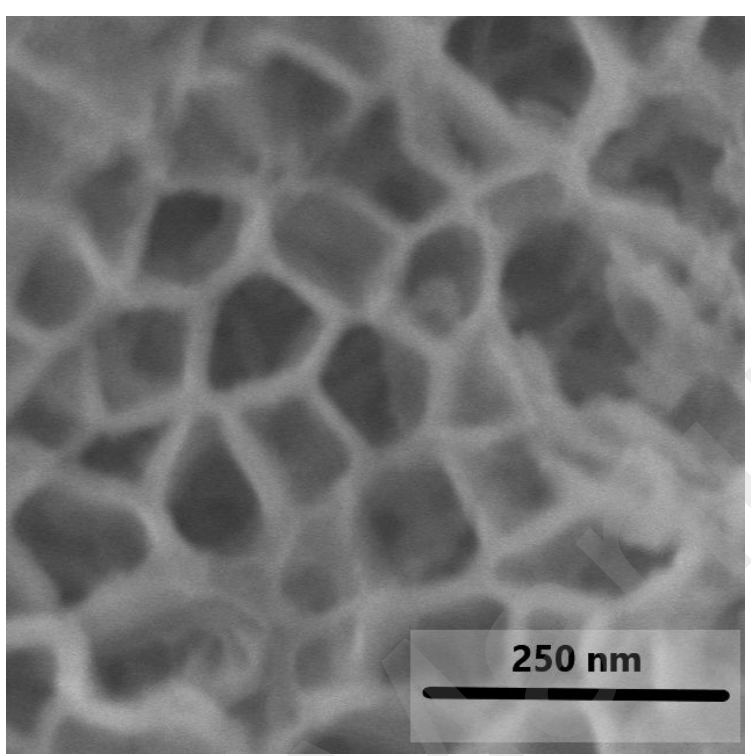

Figure 3. SEM image of porous silicon obtained by etching in $1 \%[\mathrm{HMIM}]\left[\mathrm{BF}_{4}\right] \mathrm{w}-\mathrm{IL}$ system within 1 hour at a current density of $24 \mathrm{~mA} / \mathrm{cm}^{2}$.

During etching gas formation is observed, but the change in the amount of water cannot be determined within the measurement accuracy, and after the process the system remains liquid. It contain white amorphous solid.

The increase of water content in the IL significantly affects the nature of etching. So, at $5 \%$ water in IL the morphology of the formed layer changed now resembling to a 
network of bulges around deeper etching zones of commensurate size (Fig. S2). This case is intermediate between the cellular structure (Fig. 2,3) and a spongy surface when etching is achieved with higher water content (10\%) (Fig. S3).

Elucidating the role of anion in the etching process encounters the intrinsic difficulties of strongly varying electrochemical properties of ILs when changing the anion.

Alkylimidazolium ILs with $\mathrm{PF}_{6}{ }^{-}$anion have about ten times higher viscosity and ten-fold lower conductivity than with $\mathrm{BF}_{4}^{-},[36]$ which dramatically alters etching efficiency with [HMIM][PF 6 . The process becomes non-uniform developing locally (Fig. S5, S6), though at the bottom of the affected zones the dilution of the IL with etching products

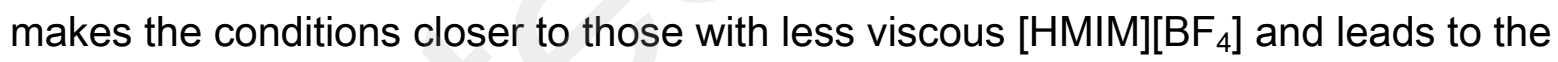
formation of a similar cellular structure (Fig. S6). Thus, changing the counterion to $\mathrm{PF}_{6}{ }^{-}$ has significant impact on the surface structure and the viscosity effects point at a diffusion-based process.

When the difference in viscosity/conductivity is smaller, ca. 2 times, finer tuning of etching properties is seen. An isotropic electropolishing occurs (Fig. S4) with 


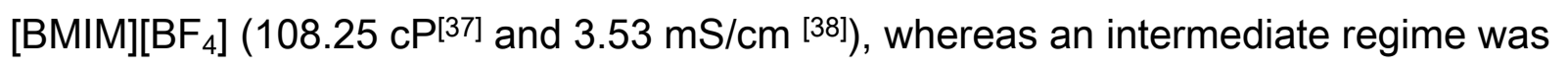
observed with [BMIM][PF 6 (284.49 $\mathrm{cP}^{[37]}$ and $\left.1.65 \mathrm{mS} / \mathrm{cm}^{[39]}\right)$ when mesoporous etching (Fig. 4 a) goes concomitantly with the formation of a sub $100 \mathrm{~nm}$ pattern (Fig. 4 c).

It should be noted that the formation of pores occurs without significant oxidation of the silicon surface, as the fraction of silicon oxide in the resulting material is less than $1.5 \%$ (according energy dispersive X-ray spectroscopy (EDS) data).

One of the essential qualities of porous silicon is its strong fluorescence. ${ }^{[40-41]}$ The fluorescence spectrum of a porous silicon sample obtained by etching in $1 \%$ $[\mathrm{HMIM}]\left[\mathrm{BF}_{4}\right] \mathrm{w}$-IL system at a current density of $8 \mathrm{~mA} / \mathrm{cm}^{2}$ for 6 hours (Fig. 5) has a maximum in blue light at $475 \mathrm{~nm}$. A more detailed study of the optical properties of the material is the subject of further study. 

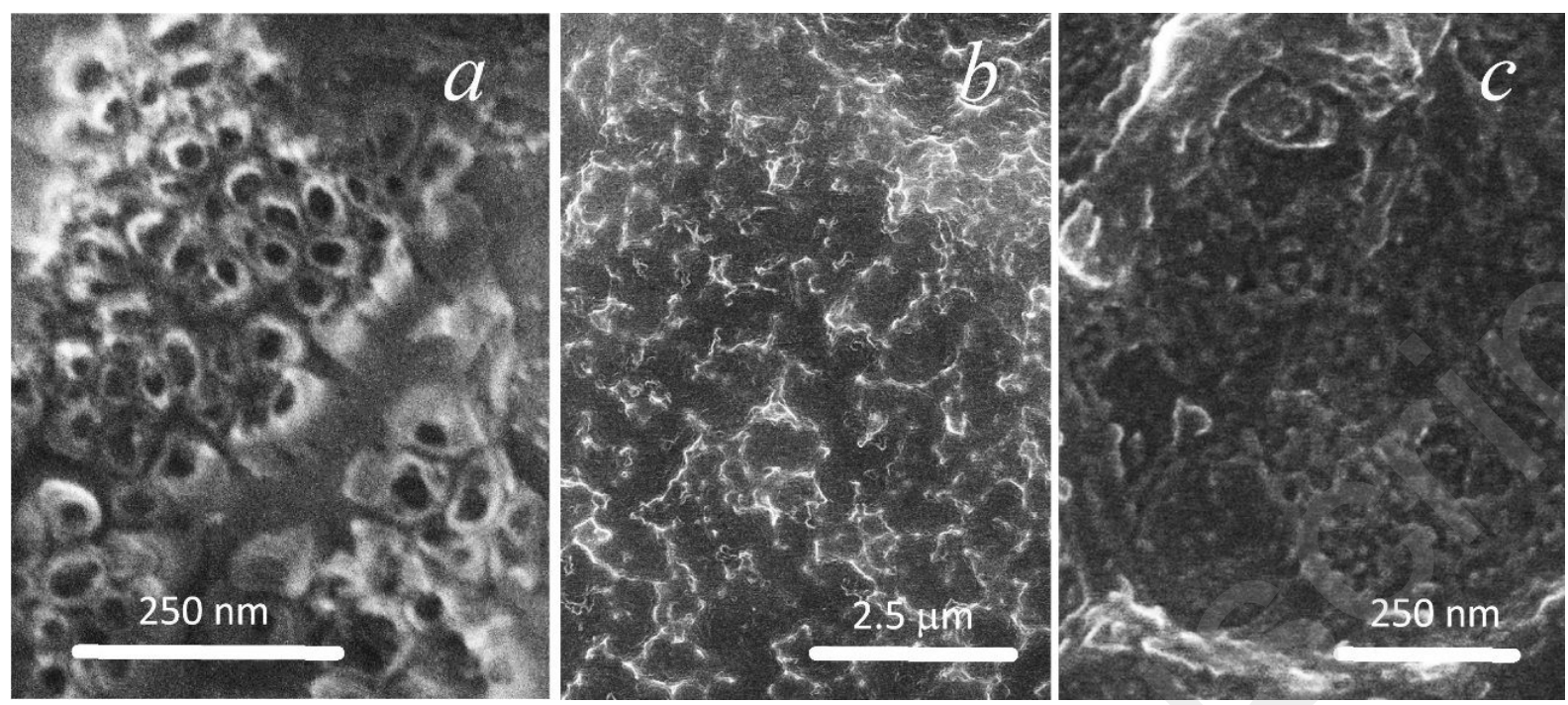

Figure 4. SEM images of a silicon samples etched in w-ILs with $\left[\mathrm{PF}_{6}{ }^{-}\right]$anion: (a)

[HMIM] $\left[\mathrm{PF}_{6}\right]$ (water content $2 \%$ ) for 1 hour at $\mathrm{j}=24 \mathrm{~mA} / \mathrm{cm}^{2}$, (b) and (c) [BMIM][PF 6

(water content $1 \%$ ) for 1 hour at $\mathrm{j}=24 \mathrm{~mA} / \mathrm{cm}^{2}$ ).

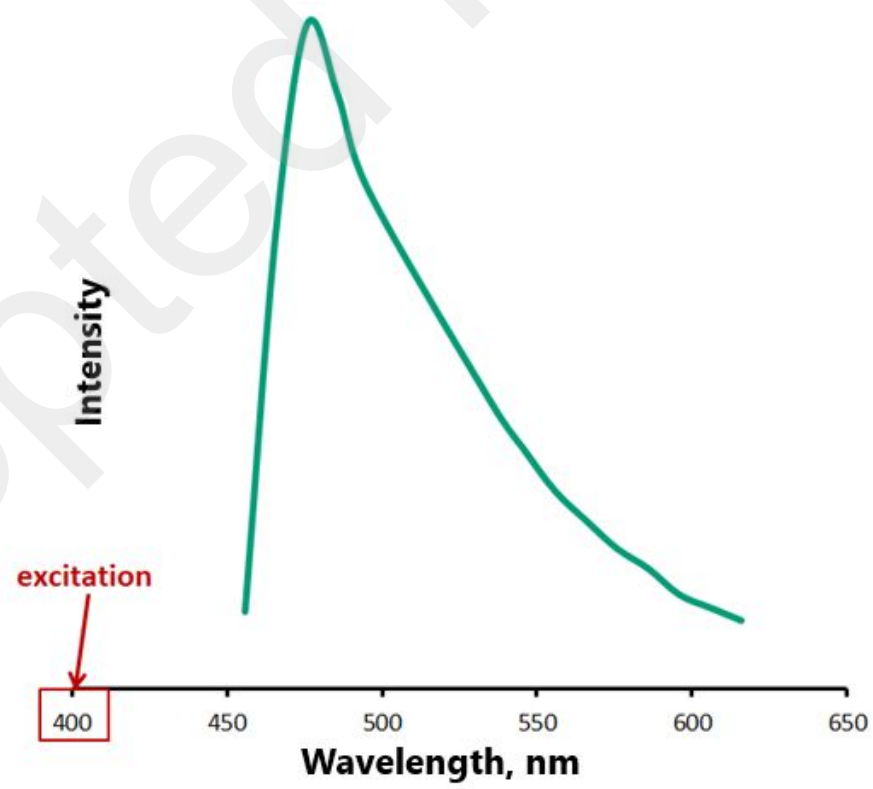


Figure 5. The fluorescence spectrum (excitation at $401 \mathrm{~nm}$ ) of a porous silicon sample obtained by etching in $1 \%\left[\mathrm{HMIM}_{[}\left[\mathrm{BF}_{4}\right] \mathrm{w}\right.$-IL system during 6 hours at $\mathrm{j}=8 \mathrm{~mA} / \mathrm{cm}^{2}$. Raman spectra of the studied samples (Fig. S19, S20) are quite similar, with the more pronounced $2 \mathrm{TO}$ mode of the etched silicon, especially with the $532 \mathrm{~nm}$ excitation.

The IL used for preparing the wafer as in Fig. 2 (right) was diluted with $\mathrm{CD}_{3} \mathrm{CN}$, and a comprehensive range of ${ }^{1} \mathrm{H},{ }^{13} \mathrm{C},{ }^{11} \mathrm{~B}$, and ${ }^{19} \mathrm{~F}$ NMR spectra were recorded. Comparison of NMR spectra of this IL before and after etching showed that it does not decompose during the etching process (all signals at all nuclei before and after etching are completely identical and only the acidic proton signal shifts to the region of the high fields, which indicates a some decrease in $\mathrm{pH}^{[42]}$ ) and it can be considered as a potentially recyclable etching agent (see Fig. S7-S14). Of course, the interpretation that the ionic liquids will be recyclable because there is no degradation of the IL as determined by NMR spectroscopy is just a preliminary investigation; and, we will need to be examined more closely in the future including examination of the purity of the IL after several uses and using a more sensitive technique. 


\section{Experimental}

Reagents, solvents, and materials. [BMIM][BF 4 (99\%), used for etching, was supplied

by Sigma Aldrich. [BMIM][PF 6 ] $(99 \%)$ was supplied by $A B C R$. $[\mathrm{HMIM}]\left[\mathrm{BF}_{4}\right]$ and

[HMIM] $\left[\mathrm{PF}_{6}\right]$ were prepared from 1-methylimidazol, $99 \%$ (Acros) and fluoroboric acid,

$48 \mathrm{wt} \%$ (Acros) or hexafluorophosphoric acid, 55 wt \% (Sigma Aldrich) respectively.

Ionic liquid systems were washed with ethyl acetate (Acros).

The n-type (111) single-crystalline silicon wafer $(\mathrm{d}=5 \mathrm{~mm}$, thickness $=2 \mathrm{~mm})$ was

polished to a high gloss with chromium oxide GOI polishing paste and then degreased

with isopropyl alcohol (SEM/EDS - see Fig.S1).

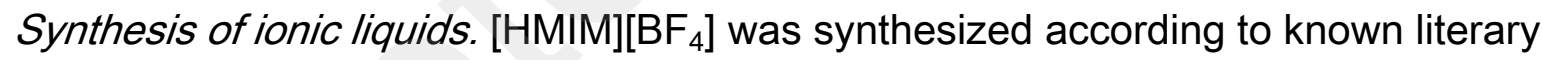

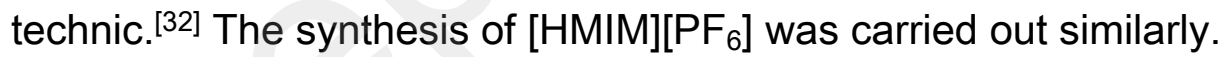

The purity and structure of prepared $[\mathrm{HMIM}]\left[\mathrm{BF}_{4}\right]$, [HMIM] $[\mathrm{PF} 6]$ were confirmed by ${ }^{1} \mathrm{H}$,

${ }^{13} \mathrm{C},{ }^{11} \mathrm{~B},{ }^{19} \mathrm{~F}$ and ${ }^{31} \mathrm{P}$ NMR analysis (see $\left.\mathrm{SI}\right)$. The NMR spectra of $\left[\mathrm{HMIM}\left[\mathrm{BF}_{4}\right]\right.$ in

$\mathrm{CD}_{3} \mathrm{CN}:{ }^{1} \mathrm{H}$ NMR $(600 \mathrm{MHz}): 3.84\left(\mathrm{~s}, 3 \mathrm{H}, \mathrm{CH}_{3}\right), 7.30(\mathrm{~s}, \mathrm{H}), 7.32(\mathrm{~s}, \mathrm{H}), 8.26(\mathrm{~s}, \mathrm{H})$, 
$12.05\left(\mathrm{~s}, \mathrm{~N}^{+}-\mathrm{H}\right) .{ }^{13} \mathrm{C}$ NMR $(150 \mathrm{MHz}): 34.2,116.9,121.9,136.8 .{ }^{11} \mathrm{~B}$ NMR $(193 \mathrm{MHz}):-$
$1.06(\mathrm{~s}) .{ }^{19} \mathrm{~F}$ NMR $(565 \mathrm{MHz}):-150.99\left(\mathrm{~s},{ }^{10} \mathrm{BF}_{4}\right)$ and $-151.04\left(\mathrm{~s},{ }^{11} \mathrm{BF}_{4}\right)$ in $1: 4$ intensity ratio, which corresponding to the natural abundance of ${ }^{10} \mathrm{~B}$ and ${ }^{11} \mathrm{~B}$ isotopes in ca. $20 \%$ and ca. $80 \%$, respectively. The NMR spectra of $\left[\mathrm{HMIM}\left[\mathrm{PF}_{6}\right]\right.$ in $\mathrm{D}_{2} \mathrm{O}:{ }^{1} \mathrm{H}$ NMR $(600$ $\mathrm{MHz}): 3.65$ (s, 3H, $\left.\mathrm{CH}_{3}\right), 7.16(\mathrm{~s}, 2 \mathrm{H}), 8.37$ (s, H). ${ }^{13} \mathrm{C} \mathrm{NMR}(150 \mathrm{MHz}): 35.3,119.3$, 122.8, 134.8. ${ }^{31} \mathrm{P}$ NMR (243 MHz): -145.3 (sep, J = 709.17 Hz) ${ }^{19} \mathrm{~F} \mathrm{NMR} \mathrm{(565} \mathrm{MHz):} \mathrm{-}$ $72.85(\mathrm{~d}, \mathrm{~J}=709.14 \mathrm{~Hz})$

NMR spectra were recorded on Bruker AV600 spectrometer at ambient temperature. Standards according to Bruker almanac ${ }^{[43]}$ were used. Water content in the ILs was controlled by Fischer titration using a KAS-01 MD apparatus.

Electrochemical etching. The etching was carried out in a PTFE cell of the original design (see Fig. 1). It consisted of a PTFE rod fitted with a PTFE nut with a $4 \mathrm{~mm}$ hole that allowed the silicon wafer to be pressed against a stainless steel rod, which served as a current collector. A PTFE nut also allows us to limit the etching area, so it remains constant throughout all experiments. In parallel with the silicon wafer, a platinum grid 
cathode was fixed above the PTFE cell. The etching agent was placed on the surface of the silicon wafer using a micropipette. The etching process was carried out in galvanostatic mode at current density in the range from $8 \mathrm{~mA} / \mathrm{cm}^{2}$ to $24 \mathrm{~mA} / \mathrm{cm}^{2}$ using a PC-piloted digital potentiostat IPC-Pro-MF (Econix). Etching time was varied from 30 minutes to 6 hours. After that, the silicon wafer was washed with ethyl alcohol and stored in a high-purity argon atmosphere in a septum-sealed vial.

SEM/EDS. Morphology of pristine and etched silicon surface was studied using a Hitachi SU8000 field-emission scanning electron microscope (FE-SEM). The images were acquired in secondary electron mode at $20 \mathrm{kV}$ accelerating voltage and the working distance 8-10 mm. Energy-dispersive X-ray spectroscopy (EDS) was carried out using an Oxford Instruments X-max 80 EDS system at $20 \mathrm{kV}$ accelerating voltage and a working distance $15 \mathrm{~mm}$. The samples were studied without metallization in order to avoid metal coating effects. ${ }^{[44]}$ 


\author{
Raman spectroscopy. Raman spectra were acquired with a BWS415 spectrometer \\ (BWTEK, Germany) with $785 \mathrm{~nm}$ laser, and with EnSpectr532 spectrometer (Enspectr, \\ Russia), integrated with $532 \mathrm{~nm}$ laser and CX41 microscope (Olympus, Japan).
}

Confocal microscopy. Confocal microscopy was performed with Nikon A1 confocal microscope equipped with $401 \mathrm{~nm}$ and $514 \mathrm{~nm}$ lasers and spectral detector (Nikon, Japan).

\title{
Summary
}

High-purity porous silicon with uniform and size-controlled pores was produced using wet 1-methylimidazolium tetrafluoroborate as the etching solution. Such a non-volatile, non-flammable, and chemically and electrochemically stable system is a good alternative to commonly used aggressive, toxic and dangerous HF. ${ }^{[45] 1-}$ Methylimidazolium tetrafluoroborate is easily synthesized and does not require special storage conditions. Moreover, it can be considered as a potentially recyclable etching agent. Besides, the etching process is very simple, secure and efficient with no need of additional heating, control of potential or any other special precautions. All this makes 


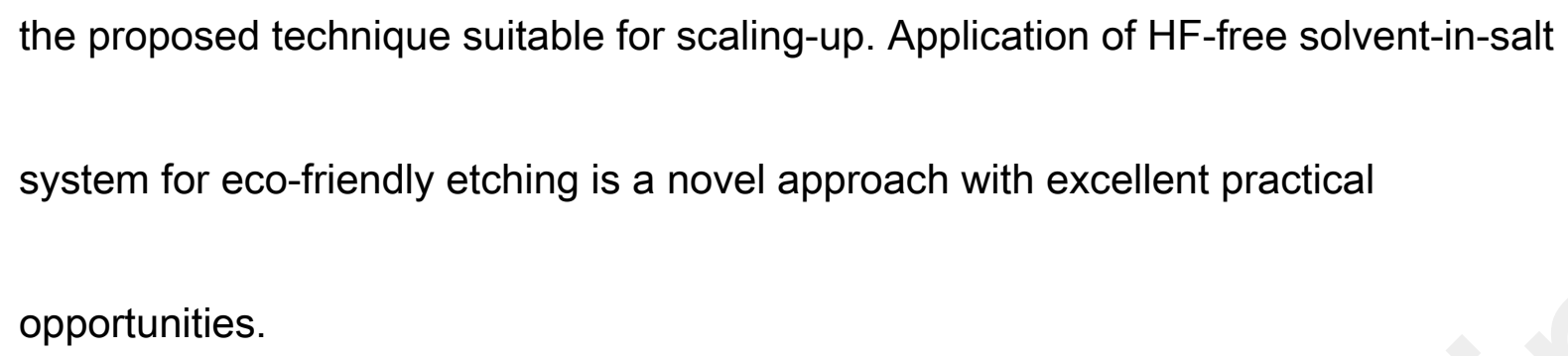


* Dr. M. A. Syroeshkin

E-mail: syroeshkin@ioc.ac.ru

${ }^{*}$ Prof. Dr. V. V. Jouikov

E-mail: vjouikov@univ-rennes1.fr

\section{Author Contributions}

All authors contributed equally.

\section{Funding Sources}

\section{ACKNOWLEDGMENT}

(E.A.S., M.P.E., M.A.S. acknowledge the support by Russian Science Foundation Grant

17-73-20281. Electron microscopy and NMR spectra characterization were performed

at the Department of Structural Studies of Zelinsky Institute of Organic Chemistry,

Moscow. Raman spectroscopy and confocal microscopy were performed by A.A.N. and

M.V.G., and were funded by the Ministry of Science and Higher Education of the

Russian Federation within the State Assignment (project 0768-2020-0007). 


\begin{abstract}
ABBREVIATIONS
[BMIM][BF4], 1-Butyl-3-methylimidazolium tetrafluoroborate; EDS, energy dispersive X-

ray spectroscopy; EMIMF-2.3HF, 1-ethyl-3-methylimidazolium oligofluorohydrogenate;

IL, ionic liquid; [HMIM][BF4], 1-Methylimidazolium tetrafluoroborate; [HMIM][PF6], 1-

Methylimidazolium hexafluorophosphate; NMR, nuclear magnetic-resonance; PTFE,

polytetrafluorethylene; PSi, porous silicon; SEM, scanning electron microscope; w-IL, wet ionic liquids.
\end{abstract}

\title{
REFERENCES
}

1. Shin, D. H.; Kim, J. M.; Jang, C. W.; Kim, J. H.; Kim, S.; Choi, S. H. Effect of Layer Number and Metal-Chloride Dopant on Multiple Layers of Graphene/Porous Si Solar Cells. J. Appl. Phys. 2018, 123 (12), 123101. https://doi.org/10.1063/1.5013169.

2. Mohammed, M. S.; Shlaga, R. A. Reflectivity Effect of the PS on Solar Cell Efficiency. In Journal of Physics: Conference Series; 2018.

https://doi.org/10.1088/1742-6596/1032/1/012027. 
3. Praveenkumar, S.; Lingaraja, D.; Mahiz Mathi, P.; Dinesh Ram, G. An

Experimental Study of Optoelectronic Properties of Porous Silicon for Solar Cell

Application. Optik (Stuttg). 2019, 178, 216-223.

https://doi.org/10.1016/j.jileo.2018.09.176.

4. Juzeliū Nas, E.; Fray, D. J. Silicon Electrochemistry in Molten Salts. Chem. Rev.

2020, 120, 3, 1690-1709. https://doi.org/10.1021/acs.chemrev.9b00428.

5. Korotcenkov G., Rusu E., How to Improve the Performance of Porous

Silicon-Based Gas and Vapor Sensors? Approaches and Achievements. Phys.

Status Solidi Appl. Mater. Sci., 2019, 216, 1900348.

https://doi.org/10.1002/pssa.201900348.

6. Wang J., Jia Z., Metal Nanoparticles/Porous Silicon Microcavity Enhanced

Surface Plasmon Resonance Fluorescence for the Detection of DNA. Sensors,

2018, 18, 661. https://doi.org/10.3390/s18020661. 
7. Terracciano, M.; Rea, I.; Borbone, N.; Moretta, R.; Oliviero, G.; Piccialli, G.; De

Stefano, L. Porous Silicon-Based Aptasensors: The Next Generation of Label-

Free Devices for Health Monitoring. Molecules 2019, 24 (12), 2216.

https://doi.org/10.3390/molecules24122216.

8. Ge, D.; Shi, J.; Wei, J.; Zhang, L.; Zhang, Z. Optical Sensing Analysis of Bilayer

Porous Silicon Nanostructure. J. Phys. Chem. Solids 2019, 130, 217-221.

https://doi.org/10.1016/j.jpcs.2019.03.002.

9. Harraz, F. A. Porous Silicon Chemical Sensors and Biosensors: A Review.

Sensors Actuators, B Chem. 2014, 202, 897-912.

https://doi.org/10.1016/..snb.2014.06.048.

10. Gopal, S.; Chiappini, C.; Penders, J.; Leonardo, V.; Seong, H.; Rothery, S.;

Korchev, Y.; Shevchuk, A.; Stevens, M. M. Porous Silicon Nanoneedles

Modulate Endocytosis to Deliver Biological Payloads. Adv. Mater. 2019, 31

(12), 1806788. https://doi.org/10.1002/adma.201806788. 
11. Park, Y.; Yoo, J.; Kang, M. H.; Kwon, W.; Joo, J. Photoluminescent and Biodegradable Porous Silicon Nanoparticles for Biomedical Imaging. J. Mater. Chem. B. 2019, 7, 6271-6292. https://doi.org/10.1039/c9tb01042d.

12. Santos, H. A.; Mäkilä, E.; Airaksinen, A. J.; Bimbo, L. M.; Hirvonen, J. Porous Silicon Nanoparticles for Nanomedicine: Preparation and Biomedical Applications. Nanomedicine. 2014, 9, 535-554.

https://doi.org/10.2217/nnm.13.223.

13. Tieu, T.; Alba, M.; Elnathan, R.; Cifuentes-Rius, A.; Voelcker, N. H. Advances in Porous Silicon-Based Nanomaterials for Diagnostic and Therapeutic Applications. Adv. Ther. 2019, 2 (1), 1800095. https://doi.org/10.1002/adtp.201800095.

14. Zhang, D. X.; Esser, L.; Vasani, R. B.; Thissen, H.; Voelcker, N. H. Porous Silicon Nanomaterials: Recent Advances in Surface Engineering for Controlled Drug-Delivery Applications. Nanomedicine. 2019, 14, 3213-3230.

https://doi.org/10.2217/nnm-2019-0167. 
15. Alhmoud, H., Brodoceanu, D., Elnathan, R., Kraus, T., Voelcker, N.H., A MACEing Silicon: Towards single-step etching of defined porous nanostructures for biomedicine, Progress in Materials Science. 2019, 100636. doi: https://doi.org/10.1016/j.pmatsci.2019.100636.

16. Jones, E. C. L.; Bimbo, L. M. Crystallisation Behaviour of Pharmaceutical Compounds Confined within Mesoporous Silicon. Pharmaceutics 2020, 12 (3), 214. https://doi.org/10.3390/pharmaceutics12030214.

17. E. Quiroga-González, H. Föll, In: Porous Silicon: From Formation to Application, Ed. G. Korotchenkov, Ch.2, CRC Press, 2016, 29-46.

18. Peng, J.; Liu, R.; Peng, L.; Jia, H. Calcium Gluconate Alleviates the Toxic Effect of Hydrofluoric Acid on Human Dermal Fibroblasts through the Wnt/B-catenin Pathway. Oncol. Lett. 2018, 16 (3), 2921-2928.

https://doi.org/10.3892/ol.2018.8975. 
19. V. Jouikov, A. Zizumbo, Eur. Pat. 16305617.9, 27.05.2016.

https://patentscope.wipo.int/search/en/detail.jsf?docld=WO2017203063, accessed 10.06.2020.

20. Zhao, S.; Zhang, Q.; Lv, Y.; Wang, X. An HF-Free Etching of $\mathrm{SiO}_{2}$ for Soft Lithography. IEEE Trans. Nanotechnol. 2016, 15 (4), 666-670.

https://doi.org/10.1109/TNANO.2016.2572120.

21. Kumar, V.; Potdevin, A.; Boutinaud, P.; Boyer, D. HF-Free Synthesis of $\mathrm{K}_{2} \mathrm{SiF}_{6}$

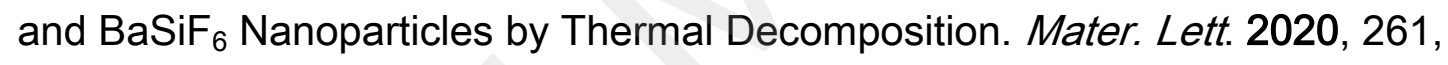
127123. https://doi.org/10.1016/j.matlet.2019.127123.

22. Teo, W. L.; Ariff, S. K. B.; Zhou, W.; Jana, D.; Phua, S. Z. F.; Zhao, Y. Solventand HF-Free Synthesis of Flexible Chromium-Based MIL-53 and MIL-88B. ChemNanoMat 2020, 6 (2), 204-207. https://doi.org/10.1002/cnma.201900665. 
23. Fialho, L.; Almeida Alves, C. F.; Marques, L. S.; Carvalho, S. Development of Stacked Porous Tantalum Oxide Layers by Anodization. Appl. Surf. Sci. 2020, 511, 145542. https://doi.org/10.1016/j.apsusc.2020.145542.

24. Greaves T. L., Drummond C. J., Protic ionic liquids: properties and applications. Chem. Rev. 2008, 108, 206-237. https://doi.org/10.1021/cr068040u.

25. Buzzeo M.C., Evans R.G., and Compton R.G., Non-haloaluminate roomtemperature ionic liquids in electrochemistry-a review. ChemPhysChem, 2004, 5, 1106-1120. https://doi.org/10.1002/cphc.200301017.

26. Silvester D.S., Compton R.G., Electrochemistry in Room Temperature Ionic Liquids: A Review and Some Possible Applications. Zeitschrift Für Physikalische Chemie, 2006, 220(10), 1247-1274. https://doi.org/10.1524/zpch.2006.220.10.1247.

27. Liu H., Liu Y., Li J., Ionic liquids in surface electrochemistry. Phys. Chem. Chem. Phys., 2010, 12, 1685-1697. https://doi.org/10.1039/B921469K 
28. Cvjetko Bubalo, M.; Vidović, S.; Radojčić Redovniković, I.; Jokić, S. Green Solvents for Green Technologies. J. Chem. Technol. Biotechnol. 2015, 90 (9), 1631-1639. https://doi.org/10.1002/jctb.4668.

29. Yoo, C. G.; Pu, Y.; Ragauskas, A. J. Ionic Liquids: Promising Green Solvents for Lignocellulosic Biomass Utilization. Curr. Opin. Green Sustain. Chem., 2017, 5, 5-11. https://doi.org/10.1016/j.cogsc.2017.03.003.

30. Earle, M. J.; Seddon, K. R. Ionic Liquids. Green Solvents for the Future. Pure and Applied Chemistry, 2000, 72, 1391. https://doi.org/10.1351/pac200072071391.

31. Egorova, K. S.; Gordeev, E. G.; Ananikov, V. P. Biological Activity of Ionic Liquids and Their Application in Pharmaceutics and Medicine. Chem. Rev., 2017, 117, 7132-7189. https://doi.org/10.1021/acs.chemrev.6b00562. 
32. Janus E., Goc-Maciejewska I., Łozyn'ski M., Pernakb J., Diels-Alder reaction in protic ionic liquids. Tetrahedron Lett. 2006, 47, 4079-4083.

https://doi.org/10.1016/j.tetlet.2006.03.172.

33. Azov, V. A.; Egorova, K. S.; Seitkalieva, M. M.; Kashin, A. S.; Ananikov, V. P. "Solvent-in-Salt" Systems for Design of New Materials in Chemistry, Biology and Energy Research. Chem. Soc. Rev., 2018, 47, 1250-1284.

https://doi.org/10.1039/c7cs00547d.

34. Ramizy A., Ibrahim I. M., Hammadi M. A., The Effect of Etching Current Density on Porous Silicon Fabricated by Electrochemical Etching Process. International Journal of Scientific \& Engineering Research, 2016, 7 (4) 717-722.

35. Al-Husseini A. M., Influence of Current Density on Morphology of Electrochemically Formed Porous Silicon. Jordan J Phys, 2016, 9, 47. 
36. Susan M. A. B. H., Noda A., Mitsushima S., Watanabe M., Brønsted acid-base ionic liquids and their use as new materials for anhydrous proton conductors. Chem. Comm. 2003, 938-939. https://doi.org/10.1039/B300959A

37. Datasheets, SOLVIONIC SASite SME, www.solvionic.com, accessed 10.06.2020.

38. Stoppa A., Hunger J., Buchner R., Conductivities of Binary Mixtures of Ionic Liquids with Polar Solvents. J. Chem. Eng. Data 2009, 54, 2, 472-479. https://doi.org/10.1021/je800468h

39. Nakamura K., Shikata T., Systematic Dielectric and NMR Study of the lonic Liquid 1-Alkyl-3-Methyl Imidazolium. ChemPhysChem, 2010, 11(1), 285-294. https://doi.org/10.1002/cphc.200900642

40. Gu, L.; Hall, D. J.; Qin, Z.; Anglin, E.; Joo, J.; Mooney, D. J.; Howell, S. B.; Sailor, M. J. In Vivo Time-Gated Fluorescence Imaging with Biodegradable 
Luminescent Porous Silicon Nanoparticles. Nat. Commun. 2013, 4 (1), 1-7.

https://doi.org/10.1038/ncomms3326.

41. Liu, C.; Jia, Z.; Lv, X.; Lv, C.; Shi, F. Enhancement of QDs' Fluorescence Based on Porous Silicon Bragg Mirror. Phys. B Condens. Matter 2015, 457, 263-268. https://doi.org/10.1016/j.physb.2014.10.005.

42. It should be noted that the technique for producing IL involves addition of acid to 1-methylimidazole, and in order to exclude the presence of acid in the product the latter is taken in a minimal excess. The impurity of 1-methylimidazole in the product is removed by repeated extraction with ethyl acetate. The resulting

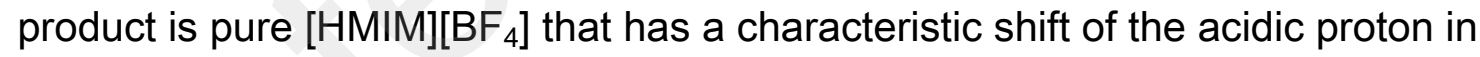
acetonitrile near $12 \mathrm{ppm}$, which is identical to the published data (see Ref. 32).

Taking into account the liquid state of the salt, it is actually a non-buffered solution with acid-base equilibrium. During etching, 1-methylimidazole, partially formed by dissociation of the salt, can be oxidized and an appearing impurity of $\mathrm{HBF}_{4}$, even in such a small amount not being detected in all spectral data (the 
shifts of all other protons remain the same after etching, ${ }^{11} \mathrm{~B}$ and ${ }^{19} \mathrm{~F}$ spectra are also identical), can cause a significant high field shift of the acidic proton. In support of this explanation, we have taken a cyclic voltammetry measurement of $[\mathrm{HMIM}]\left[\mathrm{BF}_{4}\right]$ under the same conditions as were during etching but in the presence of 1-methylimidazole. It was revealed that its oxidation begins at rather low potentials, namely $+0.8 \mathrm{~V}$ vs. $\mathrm{Ag} / \mathrm{AgCl}$ (the wave does not have a pronounced maximum because of high viscosity of the system), which is significantly lower than the real etching potential (> $2 \mathrm{~V}$ vs. $\mathrm{Ag} / \mathrm{AgCl})$. Also ${ }^{1} \mathrm{H}$

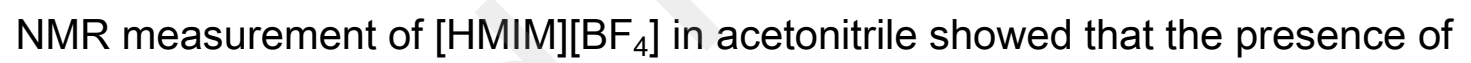
3 mol\% $\mathrm{HBF}_{4}$ (a minimal amount that can be added to a NMR tube with reasonable accuracy) causes a high field shift of the acidic $\mathrm{NH}$-proton signal by 3 ppm.

43. Bruker corporation, Almanac, 2010, ISBN 978-3-929431-24-7, Chemical Shift Ranges and Standards for Selected Nuclei, https://www.pascal$\underline{\text { man.com/pulseprogram/Almanac2010.pdf, accessed 10.06.2020 }}$ 
44. Kashin, A. S.; Ananikov, V. P. A SEM Study of Nanosized Metal Films and Metal Nanoparticles Obtained by Magnetron Sputtering. Russ. Chem. Bull. 2011, 60 (12), 2602-2607. https://doi.org/10.1007/s11172-011-0399-x.

45. It should be noted that a technique of etching silicon using ionic liquid 1-ethyl-3methylimidazolium oligofluorohydrogenate (EMIMF-2.3HF) has been published in the literature. However, HF is also actually present in such a system. Raz, O., Starosvetsky, D., Tsuda, T., Nohira, T., Hagiwara, R., Ein-Eli, Y. Macroporous Silicon Formation on n-Si in Room-Temperature Fluorohydrogenate Ionic Liquid, Electrochem. Solid-State Lett., 2007, 10, D25D28. https://doi.org/10.1149/1.2409058. 


\section{For Table of Contents}




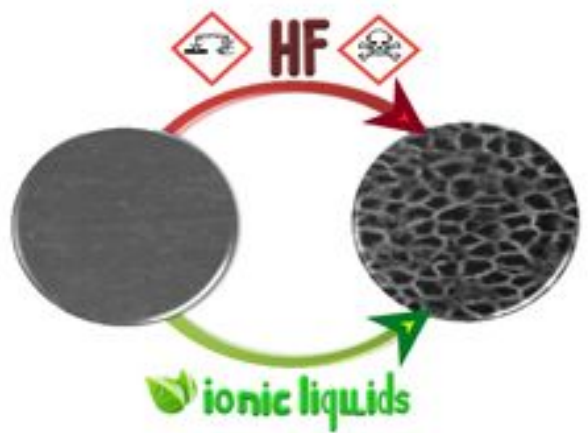

ACS Paragon Plus Environment 